Crimea and hybrid war in Eastern Ukraine have reduced the pro-Russian constituency and today Ukrainian support for NATO and EU membership stands at a record high of nearly 50 and 60 per cent respectively.

Menon and Rumer repeatedly point to how the West did not see the crisis coming or anticipate Russia's moves "which at every step exceeded Western expectations" (159). Towards this end, they argue for Western strategy to be "built on a realistic understanding of Russia rather than on what the West would like it to be and hopes it will one day become" (162). Menon and Rumer are right to question the naivety of the "Russia reset" by the Obama administration and the cozying up of Germany, France, Italy, and other EU members to a Russia transforming into an authoritarian and xenophobic anti-Western regime.

At the same time, if Western leaders were to accept the advice offered by Menon and Rumer it would amount to an appeasement of Russia's interests and a turn away from their core values. The seeds of the Ukraine crisis are not just in big power politics but also in Russian chauvinism towards its neighbours that has always existed and which evolved into a coherent set of aggressive policies over the last decade. Putin told President George W. Bush in 2008 "You know George, Ukraine isn't even a country" - a view that rules out any Ukrainian leader agreeing to his country becoming a Russian buffer as this would not be "Finlandization" but a vassal state. Therefore, unsurprisingly Menon and Rumer fail to grasp how pro-Russian presidents of Ukraine Leonid Kuchma and Viktor Yanukovych (63) also had difficult relations with Moscow, even when in the latter case they agreed to all Russian demands and nevertheless, Ukraine was charged the highest gas price in Europe.

With an over-focus on big power politics Menon and Rumer miss the bigger domestic picture and therefore their book fails to understand the sources of Ukraine's conflict.

Taras Kuzio

Canadian Institute of Ukrainian Studies, University of Alberta

\title{
James M. Pitsula, Keeping Canada British: The Ku Klux Klan in 1920s Saskatchewan (Vancouver: University of British Columbia Press, 2013). 308 pp. $\$ 95.00$ Hardback.
}

This well written, sprightly book offers a serious revision of the role the $\mathrm{Ku}$ Klux Klan played in Saskatchewan during the 1920s. It is dissociated from its United States roots and quite thoroughly placed into mainstream Saskatchewan history. It infers that its image as a fanatical group - that hooded, violent and anti-Semitic group of the US Klan - was the result of campaign caricaturing by the James Gardiner government. The KKK in Saskatchewan is by no means rendered as an open and liberal group, but it is rendered nevertheless as a typically 
anti-immigrant, pro-British and monarchical organism, consisting of members of the "lower middle class and upper working class" (91). Its wider concerns were those shared by most folks of European descent in Saskatchewan: it was worried about out-of-control youth and unsteady marriages in an age of "flapperdom" (184), and it was committed to social reform, entailing a virulent opposition to "alcohol, opium, gambling and prostitution" (20). And it shared the imperial, Protestant-based agenda of a British-oriented "white man's burden" (111). Even its seamier qualities are portrayed as relatively moderate for the day: it was patriarchal while claiming to "adorn" women (67), it spoke of a racialised fear of non-whites but "never mentioned Aboriginal peoples," (7) and it drew a great deal of support from rank and file Liberals (90). Pitsula's thesis is clear: the meager but influential historiography on the KKK has left the impression that "Saskatchewan went berserk for a while," when in fact the "Klan was not something alien to Saskatchewan; it was Saskatchewan" (14).

Pitsula emphasises a single key moment in Saskatchewan Klan history. In the fall of 1927 US organisers, having just months earlier drawn crowds of thousands as it denounced the arrival of non-English, Catholic immigrants, absconded with lucrative membership fees. The immediate result was that the Saskatchewan Klan executive turned against the US, founders with a new constitution that renounced violence, terror and white hoods. But he also emphasises the wider context of the Saskatchewan in the 1920s. Quite simply it was a combination of frenzied post-World War I British patriotism and the famous Railway Agreement that worked to turn Saskatchewan into Canada's third largest province in which a majority of citizens by 1931 were not British. In addition, the Klan filled a void left by a weak Conservative party, offering little effective opposition to the governing Liberals, and unable to articulate the vision of British Saskatchewanians.

Along the way, Pitsula not only mainstreams the Klan, his narrative of it illuminates the nature of Canada in the 1920s. As his book title suggests, he presents the majority of English speaking Canadians as pro-British, more interested in fighting imperial wars than celebrating such iconic symbols of nationalism as the Group of Seven paintings (3). And sandwiched in between the xenophobic patriotism of the First World War and the devastating wasteland of the Depression, the 1920s marked a high point of anti-immigrant and anti-foreign sentiment. In fact the reason the KKK fell off quite suddenly after the 1920 s had less to do with the scandal and violence its associates suffered in the United States, than simply because a Canadian moment had passed: the Depression left members destitute and struggling to stay alive, and the Railway Agreements that had drawn 185000 immigrants, many of whom were Germans from Russia, Ukrainians from the former Austrian Hungarian empire, ended. Moreover, Saskatchewan society in the 1920 s is a microcosm of wider Canadian cultural developments. The Klan employed radio to broadcast its message; it relied on 
fundamentalist evangelicalism to rationalize its mission; it withstood a barrage of anti-American rhetoric from a new generation of Canadian nationalists; it filtered the perennial schools' question; it employed that icon of Canadian law and order, the Royal Canadian Mounted Police.

In the conclusion, Pitsula presses the story to even further horizons. He insists that the story of the Klan in Saskatchewan is rooted in a global narrative of racialised objections to immigrants, whether in modern Western Europe, the United Kingdom or Southeast Asia. I thought that given the conclusion, and chapter segments throughout, that in some respect Pitsula protested too much. Yes, Woodsworth was racist, progressives embraced eugenics, W.L. Grant championed an "imperialism of peace" that privileged British immigrants (113), Darwinian science encouraged racialisation, and "women's leagues....expressed alarm at foreign immigration," (136) but the fact remains that the Klan was hate filled, paranoid and culturally myopic. But then perhaps this path of circumstantial evidence is the only way to capture the sentiment of members of a secret society who have not kept journals or who do not talk to neighbours. It is perhaps a history that by necessity is based on public speeches and newspaper articles.

Royden Loewen

The University of Winnipeg

\section{Donald Smith, Mississauga Portraits: Ojibwe Voices from Nineteenth- Century Canada Toronto: University of Toronto Press, 2013). 496 pp. $\$ 37.95$ Paperback.}

In Mississanga Portraits: Ojibwe Voices from Nineteenth-Century Canada, Donald Smith transports his readers to the north shore of what is now known as Lake Ontario. There readers meet eight Mississauga people - seven men and one woman many of whom were intimately connected to Credit River. ${ }^{1}$ Through Smith's eight biographic sketches, readers discover how "in a moment of social crisis [i.e. settler encroachment], namely the 1820s and 1830s, Methodism helped to see a number of Mississauga through until a new equilibrium was achieved" (286). The Anishinabeg of the north shore did not universally adopt Methodism. Readers meet individuals who adopted and adapted Christianity, and others who became disillusioned with Methodist mission work. Indeed, as Smith effectively argues, Anishinabeg men and women "reacted to Methodism in diverse ways... as they worked to create a better future for themselves, their families, and their communities" (xvii). This review offers a close reading of three chapters (and three people) that reflect the diverse responses - adoption, adaptation, and disillusionment - addressed by Smith.

Many of the individuals biographised (and hence reviewed) were social- 